Studia z Dziejów Średniowiecza, t. 23, 2019

Łukasz Włodarski

(Instytut Historii i Archiwistyki

Uniwersytet Mikołaja Kopernika w Toruniu)

\title{
Relacje arcybiskupa gnieźnieńskiego Jarosława Bogorii ze Skotnik z zakonem krzyżackim w Prusach
}

https://doi.org/10.26881/sds.2019.23.14

Keywords: Poland, archbishops of Gniezno, Pomerelia, peace treaty of Kalisz, treaty of Trzęsacz, economy, $14^{\text {th }}$ century

Osoba Jarosława Bogorii ze Skotnik, pomimo że nie doczekała się współczesnej monografii, w dyskursie historycznym obecna jest od dawna. Jeszcze w XIX w. Jan Korytkowski w swym monumentalnym dziele Arcybiskupi gnieźnieńscy przedstawił obszerny biogram Skotnickiego ${ }^{1}$. Podobnie uczyniła to zresztą Krystyna Stachowska na łamach Polskiego słownika biograficznego ${ }^{2}$. Bogoria stał się również obiektem zainteresowania Zofii Kowalskiej-Urbankowej, która próbowała (nie do końca udanie) naświetlić jego działalność polityczna, prawodawczą oraz gospodarczą ${ }^{3}$. Nie brak także wywodów genealogicznych rodu Bogoriów: tu należy wyróżnić przede wszystkim prace Zygmunta Wdowiszewskiego oraz Jana Tęgowskiego ${ }^{4}$. Z kolei o czasach

1 J. Korytkowski, Arcybiskupi gnieźnieńscy: prymasi i metropolici polscy od roku 1000 aż do roku 1821, czyli do połaczenia arcybiskupstwa gnieźnieńskiego z poznańskim, t. 1, Poznań 1888, s. 560-649.

2 K. Stachowska, Jarostaw Bogoria [w:] PSB, t. 11, Wrocław 1964-1965, s. 1-3.

3 Z. Kowalska-Urbankowa, Jarosław ze Skotnik Bogoria arcybiskup gnieźnieński. Prawodawca i dyplomata, „Nasza Przeszłość” 1985, t. 63, s. 53-96. Szczególna krytyka spadła na autorkę ze strony Stanisława Szczura (Uwagi o działalności dyplomatycznej arcybiskupa gnieźnieńskiego Jarosława Bogorii, „Nasza Przeszłość” 1987, t. 67, s. 237-247), który uwypuklił mankamenty jej pracy na niwie działalności dyplomatycznej.

4 Z. Wdowiszewski, Ród Bogoriów w wiekach średnich, „Rocznik Polskiego Towarzystwa Heraldycznego we Lwowie” 1928-1929, t. 9, s. 1-96; J. Tęgowski, Krag 
studenckich Jarosława, w pracy traktujacej o Polonii w czternastowiecznej Bolonii, pisała Zofia Kozłowska-Budkowa ${ }^{5}$, a o roli Skotnickiego w sporach polsko-krzyżackich za panowania dwóch ostatnich Piastów dowiadujemy się z prac Stanisława Szczura ${ }^{6}$. Nie brak również ukazania jego relacji z Galhardem de Carceribus, czym zajął się Tęgowski Warte odnotowania jest także opracowanie na temat dworu i najbliższego otoczenia Jarosława ${ }^{8}$.

Celem niniejszego artykułu jest ukazanie relacji, jakie istniały pomiędzy najwyższym dostojnikiem kościelnym w czternastowiecznej Polsce, Jarosławem Bogorią ze Skotnik, a zakonem krzyżackim w Prusach. Ramy chronologiczne sa wyznaczone przez pontyfikat arcybiskupa gnieźnieńskiego, tzn. lata 1342-1374 (1376), jednak dla przedstawienia szerszego kontekstu interesujacych nas wydarzeń dolna granica została przesunięta do początku XIV w.

Jarosław Bogoria Skotnicki wywodził się z możnowładczej rodziny Bogoriów, która powszechnie jest uważana za fundatorów i dobrodziejów opactwa cysterskiego w Koprzywnicy w ziemi sandomierskiej ${ }^{9}$. Za właściwego twórcę potęgi tego małopolskiego rodu przyjmuje się ojca Jarosława - Piotra - który jako pierwszy z rodziny pełnił wysokie i zaszczytne godności ${ }^{10}$. W 1268 r. na jednym z dokumentów wystapił on jako kasztelan wiślicki, a w latach 1280-1282 sprawował urząd wojewody krakowskiego. W myśl zasadnej opinii Tęgowskiego Piotr Bogoria był dwukrotnie żonaty ${ }^{11}$. Jego najstarszym synem

rodzinny Jarosława Bogorii [w:] Genealogia. Polska elita polityczna w wiekach średnich na tle porównawczym, red. J. Wroniszewski, Torun 1993, s. 123-137.

5 Z. Kozłowska-Budkowa, Polonia w Bolonii w latach 1300-1327 [w:] Cultus et cognitio. Studia z dziejów średniowiecznej kultury, red. S.K. Kuczyński, Warszawa 1976, s. 281-292.

6 S. Szczur, Traktat pokojowy Kazimierza Wielkiego z zakonem krzyżackim z 1343 roku, ZH 1991, t. 56, s. 7-43; idem, Uwagi o działalności..., s. 237-247.

7 J. Tęgowski, Kanclerz kujawski Jarosław Bogoria $i$ jego stosunki z Galhardem de Carceribus [w:] Personae, colligationes, facta, red. J. Bieniak et seq., Toruń 1991, s. 39-49.

8 Ł. Włodarski, Dwór i najbliższe otoczenie arcybiskupa gnieźnieńskiego Jarostawa Bogorii ze Skotnik (1342-1374), „Studia z Dziejów Średniowiecza” 2015, t. 19, s. 223-253. Ponadto istnieje wiele rozpraw wzmiankujących tylko o arcybiskupie, np. Z. Kaczmarczyk, Monarchia Kazimierza Wielkiego, t. 1: Organizacja państwa, Poznań 1939; J. Pakulski; Sity polityczno-społeczne w Wielkopolsce w pierwszej połowie XIV wieku, Toruń 1979.

9 S. Szczur, Uwagi o działalności..., s. 237.

10 S. Szczur, Piotr, wojewoda krakowski [w:] PSB, t. 26, Wrocław 1981, s. 369-370.

11 J. Tęgowski, Krag rodzinny..., s. 125. 
z pierwszego małżeństwa był Wojciech ze Żmigrodu. Z racji swojego starszeństwa prowadził politykę rodzinna po śmierci ojca i to on, wiążąc się z Władysławem Łokietkiem, zerwał z polityką partykularna prowadzona do tej pory przez Piotra, co wydaje się być punktem zwrotnym w dziejach rodziny. To, że Wojciech od początku wspierał działania księcia Władysława, widzimy już w momencie, kiedy wystąpił jako świadek w pierwszym znanym nam dokumencie książęcym wystawionym przez Piasta kujawskiego w Małopolsce w lutym 1305 r. $^{12}$ Wojciech musiał się bardzo wyróżnić w zasługach o utrzymanie i rozszerzenie władztwa Łokietkowego, skoro ten z początkiem $1306 \mathrm{r}$. mianował go wojewodą sandomierskim (po wielce prawdopodobnej śmierci Ottona h. Topór) ${ }^{13}$. Był on, co zrozumiałe, również obecny w czasie wjazdu księcia do Krakowa ${ }^{14}$. Kiedy ów po zainstalowaniu swojej władzy w Małopolsce już w listopadzie 1306 r. wybrał się na Pomorze Gdańskie, wraz z nim udał się także Wojciech, którego imię widnieje w testacji dyplomu wystawionego 27 listopada tego roku $\mathrm{w}$ Pelplinie ${ }^{15}$. Był on także świadkiem w procesie kanonicznym przeciw biskupowi Muskacie, który toczył się z inicjatywy arcybiskupa gnieźnieńskiego Jakuba Świnki, gdzie w rzeczywistości metropolita występował $\mathrm{w}$ dobrze pojętym interesie księcia. Mimo kościelnego charakteru procesu, poza duchowieństwem w charakterze oskarżycieli, czynnie brali w nim udział urzędnicy małopolscy, w tym Bogoria $^{16}$. Z datą 21 lutego $1312 \mathrm{r}$. zachował się przywilej dla mieszczan sądeckich wystawiony na Wawelu przez żonę Władysława, księżna Jadwigę - gdzie w liście świadków odnajdujemy wojewodę sandomierskiego Wojciecha ze Żmigrodu. W związku z tym próbuje się łączyć grupę dostojników wymienionych w testacji tegoż dokumentu z obrońcami zamku krakowskiego podczas buntu wójta Alberta, który miał miejsce w latach 1311-1312 $2^{17}$. Niemniej wedle Andrzeja Marca powyższe ustalenia nie zasługują na uznanie, aczkolwiek nie można ich w pełni wykluczyćc ${ }^{18}$. Wojciech po raz ostatni wystapił w źródłach

12 ZDM, t. 4, nr 889; A. Marzec, Urzędnicy małopolscy w otoczeniu Wtadysława Łokietka i Kazimierza Wielkiego (1305-1370), Kraków 2006, s. 22, 49.

13 UW, s. 221, 222; S. Szczur, Uwagi o działalności..., s. 238; A. Marzec, Urzędnicy..., s. 50-51.

14 A. Marzec, Urzędnicy..., s. 25.

15 P, nr 649; A. Marzec, Urzędnicy..., s. 26.

16 A. Marzec, Urzędnicy..., s. 29.

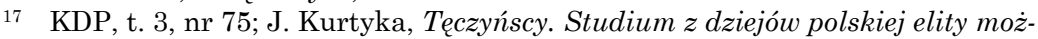
nowładczej w średniowieczu, Kraków 1997, s. 138.

18 A. Marzec, Urzędnicy..., s. 34-35. 
jako wojewoda sandomierski 16 października 1313 r., z kolei w dokumencie z 1316 r. wspomniano już o nim jako o zmarłym ${ }^{19}$.

Kolejni synowie Piotra najprawdopodobniej urodzili się z jego drugiej żony. Najstarszym z nich był Mikołaj. Swoją karierę polityczna rozpoczął kilka lat po śmierci Wojciecha. Bez zbędnego ryzyka można stwierdzić, że pozycja jego ojca, a przede wszystkim brata, pomogła mu w osiagnięciu urzędu podkomorzego krakowskiego, który dzierżył w latach (1317?)1318-1330²0, a od 1331 r. pełnił godność wojewody krakowskiego ${ }^{21}$. W 1332 r. na wiecu w Wiślicy doprowadził do zawarcia ugody pomiędzy mieszczaństwem krakowskim i sandomierskim ${ }^{22}$. Po śmierci Władysława Łokietka utrzymał swój urząd, sprawując go aż do śmierci w 1339 r. Następnie jego działalność polityczna u boku ostatniego Piasta na tronie polskim nabrała rozmachu. Mikołaj zaczą angażować się w sprawy najistotniejsze dla kraju. W 1335 r. uaktywnił się na arenie międzynarodowej, co było związane z jego udziałem w rokowaniach polsko-krzyżackich, kiedy wystapił w charakterze współwystawcy dyplomu królewskiego ${ }^{23}$. Nie zabrakło go u boku Kazimierza Wielkiego także w Wyszehradzie podczas zjazdu króla z Karolem Robertem i Janem Luksemburskim. Mikołaj, będąc dyplomata królewskim, bez wattpienia należał do najbliższego otoczenia króla Kazimierza Wielkiego - przekonuje o tym chociażby fakt powierzenia mu przez monarchę tak ważkich spraw. Bogoria najprawdopodobniej należał do tych możnowładców małopolskich, na których król Kazimierz oparł politykę w początkowej fazie swoich rządów ${ }^{24}$.

Kolejnym synem wojewody krakowskiego Piotra Bogorii był Paweł (Paszek). Działalność polityczną rozpoczął za panowania króla Kazimierza Wielkiego, kiedy to w latach 1335-1348 sprawował urząd

19 Jego następca na tym urzędzie - Nawój z Morawicy - potwierdzony jest dopiero w 1317 r. W związku z tym niewykluczone, iż Wojciech pełnił godność wojewody sandomierskiego do swojej śmierci, zob. UM, s. 221, 222; A. Marzec, Urzędnicy..., s. 51.

20 UW, s. 221; F. Sikora, Mikołaj z Bogorii [w:] PSB, t. 21, Wrocław 1976, s. 105-106; S. Szczur, Uwagi o działalności..., s. 238; A. Marzec, Urzędnicy..., s. 61 (tu autor omyłkowo przesuwa początek działalności Mikołaja na podkomorstwie krakowskim na rok 1320, zamiast 1317).

21 UW, s. 126, 126; Z. Kaczmarczyk, Monarchia..., t. 1, s. 293; S. Szczur, Uwagi o dziatalności..., s. 239.

22 KDM, t. 1, nr 188; S. Szczur, Uwagi o działalności..., s. 239.

23 Lites, t. 1, wyd. I. Zakrzewski, Poznań 1890, nr 19, 20. Również strona krzyżacka brała pod uwagę Mikołaja jako przyszłego gwaranta układu pokojowego, który miał być zawarty z Kazimierzem Wielkim, zob. S. Szczur, Uwagi o działalności..., s. 239.

24 Ibidem. 
sędziego ziemskiego sandomierskiego ${ }^{25}$. Obok swojego brata Mikołaja uczestniczył w zjeździe wyszehradzkim w 1335 r., co może wskazywać na jego silną pozycję w królewskim otoczeniu. Po 1348 r. nie odnajdujemy żadnych śladów jego działalności ${ }^{26}$.

Ostatnim znanym nam męskim potomkiem Piotra był Jarosław. Przyjmując literalnie informacje zawarte w Kronice Jana z Czarnkowa, należałoby przypuszczać, że urodził się on w 1276 r., gdyż według kroniki Skotnicki w chwili śmierci liczył sobie równo sto lat ${ }^{27}$. Ten pogląd został bezkrytycznie przyjęty w historiografii ${ }^{28}$. Niemniej Tegowski, prowadząc badania nad kręgiem rodzinnym Jarosława Bogorii, zauważył, że gdyby był on słuszny, to Skotnicki w chwili odbywania studiów w Bolonii (1316-1321) liczyłby sobie około czterdziestu lat, co akurat wydaje się być mało prawdopodobne ${ }^{29}$. W związku z powyższym datę jego narodzin należałoby umieścić w połowie lat osiemdziesiątych XIII w., jednak nie później niż w 1287 r., gdyż wówczas, przypuszczalnie, zmarł jego ojciec ${ }^{30}$.

Wiadomo, że Piotr miał co najmniej trzy córki, niestety, nie znamy imienia żadnej z nich. Pierwsza była żoną Pakosława z Januszewic i matką Janusza Suchegowilka (następcy Jarosława na tronie arcybiskupim w Gnieźnie) ${ }^{31}$, druga żoną Pakosława z Mstyczowa, a trzecia żona jednego z przedstawicieli rodu Jelitów - Nagodziców ${ }^{32}$.

Bez watpienia kariery ojca i braci Jarosława, a także mariaże sióstr musiały wpłynać na jego pozycję w Małopolsce, a później także w otoczeniu królewskim.

Zabór Pomorza Gdańskiego przez Krzyżaków w latach 1308-1309 spowodował, że tamtejsza część archidiecezji gnieźnieńskiej znalazła się pod władzą zakonu, co w konsekwencji doprowadziło do znacznych trudności w ściaganiu dziesięcin oraz w administracji tychże terenów. Dodajmy, że majątki stołu arcybiskupiego położone na Pomorzu

25 UM, s. 208.

26 S. Szczur, Uwagi o działalności..., s. 239.

27 Kronika Janka $z$ Czarnkowa (dalej: Kronika) [w:] MPH, t. 1, s. 672.

28 Z. Wdowiszewski, Ród Bogoriów..., s. 28.

29 J. Tęgowski, Krag rodzinny..., s. 123, przyp. 3.

$30 \quad$ Ibidem, s. 123.

31 A. Marzec, Krag rodzinny arcybiskupa Janusza Suchywilka, „Genealogia. Studia i Materiały Historyczne” 1996, t. 8, s. 15-18.

32 J. Tęgowski, Krag rodzinny..., s. 126, 129, 132-133. S. Szczur (Uwagi o dziatalności..., s. 240) mylnie twierdzi, że żoną Spicymira, doradcy Władysława Łokietka, była córka Piotra - Stanisława. Jak dowiódł J. Tęgowski (Krag rodzinny..., s. 131), Stanisława była wnuczką Piotra, a córką Pawła. 
również znalazły się pod rządami krzyżackimi ${ }^{33}$. Problemem były również zniszczenia wojenne - wszak arcybiskupi gnieźnieńscy toczyli własny proces z Krzyżakami (na marginesie warto dodać, że analogiczne problemy mieli również biskupi włocławscy, które to de facto stawały się również problemami metropolitów z racji ich zwierzchnictwa nad polską prowincja kościelna - niemniej to zagadnienie zasługuje na osobne potraktowanie). Wydarzenia z początku XIV stulecia spowodowały, iż Krzyżacy stali się głównymi wrogami Korony (,inimici capitales Regni”) ${ }^{34}$. Z racji szczupłości zachowanego materiału źródłowego trudno coś więcej powiedzieć o działaniach ówczesnego arcybiskupa gnieźnieńskiego Jakuba Świnki. Z pewnościa, z racji pobytu w Awinionie, żadnych działań na tym polu nie podją jego następca na tronie metropolitalnym - Borzysław. Dopiero sytuacja źródłowa z okresu pontyfikatu Janisława, a więc bezpośredniego poprzednika Jarosława na tronie gnieźnieńskim, umożliwia nam odtworzenie stosunku hierarchy do Krzyżaków oraz działań podejmowanych na tej niwie przez pierwszego dygnitarza Królestwa. Janisław czynnie uczestniczył w zjazdach w Sulejowie (1318) oraz w Żarnowie (1319), gdzie ostatecznego kształtu nabrały kwestie związane z rozpoczęciem procesu kanonicznego z Krzyżakami. Wreszcie to 11 listopada 1319 r. został, obok biskupa poznańskiego Domarata oraz opata mogileńskiego Mikołaja, wyznaczony przez papieża Jana XXII na sędziego w procesie z Krzyżakami, który toczył się w latach 1320-1321. Arcybiskup gnieźnieński wraz z biskupem włocławskim Gerwardem byli także wyznaczeni przez następcę św. Piotra na kolektorów świętopietrza m.in. w diecezji chełmińskiej, znajdującej się wówczas na terytorium władztwa krzyżackiego. W związku z tym metropolita starał się wykorzystać pobór opłat do celów politycznych, rozpoczynając ich ściaganie w przeddzień procesu polsko-krzyżackiego. Z głównych

33 Dobra arcybiskupie położone na Pomorzu i w ziemi nakielskiej były zarządzane przez prokuratora kamieńskiego. W skład tegoż klucza wchodziły następujące wsie: Brudzewo, Cerekwica Wielka, Cerekwica Mała, Obkas (=Cerekwica Nowa), Chojniczka (do 1344), Dąbrowa, Dąbrówka, Dobiszewo, Gardna Wielka, Gardna Mała, Gębarzewo (do 1354), Grizów (od 1348), Gruczno, Kamień (dawniej Wawrzyszkowo), Konotopia (do 1370), Kozielec, Lubiewo (od 1344), Lutówko (od 1372), Lutowo, Łubnia, Mochle, Orle, Płoczyce, Rybitwy, Sucha (od 1344), Warna, Witków i Zabratowo, zob. J. Warężak, Rozwój uposażenia arcybiskupstwa gnieźnieńskiego $w$ średniowieczu z uwzględnieniem stosunków gospodarczych w XIV i XV wieku, Lwów 1929, s. 140-141.

34 Szerzej na temat postrzegania Krzyżaków por. T. Nowakowski, „Inimici capitales”. Z dziejów ideologii politycznej w czternastowiecznej Wielkopolsce, „Acta Universitatis Nicolai Copernici. Historia" 1980, t. 17, s. 81-92. 
wydarzeń politycznych tamtego okresu dotyczących relacji Korony z zakonem należy wymienić obecność Janisława na zjeździe inowrocławskim w 1337 r., a w latach 1338-1339 udział w kolejnym procesie polsko-krzyżackim w Warszawie. Wypada również wspomnieć, że krótko przed śmiercia, w październiku 1341 r., metropolita brał udział w rozmowach zwaśnionych stron w Toruniu ${ }^{35}$. Tak więc bezpośredni poprzednik Jarosława na stolicy arcybiskupiej w Gnieźnie był czynnie zaangażowany w politykę zagraniczną Polski, która zmierzała do odzyskania terytoriów zagrabionych przez Krzyżaków (Pomorza, ziemi chełmińskiej oraz ziemi michałowskiej). Przejawem jego zaangażowania był przede wszystkim udział w procesach i rokowaniach polsko-krzyżackich. Jest oczywiste, że tak napięta sytuacja polityczna uniemożliwiała normalne i sprawne zarządzanie dobrami kościelnymi arcybiskupstwa gnieźnieńskiego położonymi na terenie władztwa krzyżackiego. Dodajmy, że w tym okresie nie odnajdujemy żadnych informacji o działalności gospodarczej zwiąanej z dobrami metropolitów usytuowanych na Pomorzu.

Dotychczas w literaturze przedmiotu uznawano, że Jarosław Bogoria zwrócił uwagę na sprawy krzyżackie w roku $1331^{36}$ - wówczas to został kanclerzem kujawskim i sprawował ten urząd zapewne do momentu wyboru na arcybiskupstwo gnieźnieńskie ${ }^{37}$. Należy dodać, iż obdarzenie Jarosława, przez Łokietka, kanclerstwem wpisywało się w politykę personalną prowadzoną przez monarchę polegająca na obsadzaniu urzędów kanclerskich osobami wykształconymi (zwłaszcza w prawie) ${ }^{38}$. Nie bez znaczenia jest również fakt, że urząd kanclerza kujawskiego w latach 1332-1343 był de facto urzędem fikcyjnym, gdyż wówczas Kujawy znalazły się pod panowaniem

35 M. Komaniecka, Działalność polityczna arcybiskupa Janisława, „Nasza Przeszłość” 2005, t. 103, passim (tam również starsza literatura przedmiotu).

$36 \quad$ S. Szczur, Uwagi o działalności..., s. 241. Z kolei Zofia Kowalska-Urbankowa (Jarosław ze Skotnik..., s. 67-68) twierdziła, że Jarosław zainteresował się bliżej kwestią krzyżacką dopiero u boku króla Kazimierza Wielkiego w 1337 r. podczas procesu polsko-krzyżackiego w Inowrocławiu. Według niej przebywał tam przy monarsze, jednak autorka nie podała, w jakim charakterze. Przypuszczała, że jako osoba mająca wykształcenie prawnicze mógł pełnić funkcję jakiegoś doradcy.

37 Za piastowaniem tego urzędu przez Jarosława do jego wyboru na arcybiskupa gnieźnieńskiego przemawia fakt, że ostatni raz z odnośną tytulaturą występuje 4 X 1341 r., a jego następca na tym urzędzie pojawia się dopiero 18 X 1343 r., zob. UKD, s. 144.

38 K. Ożóg, Intelektualiści w stużbie Królestwa Polskiego w latach 1306-1382, Kraków 1995, s. 29-31. 
krzyżackim (nie uwzględniając oczywiście zachodniego skrawka tej ziemi zwróconego stronie polskiej w $1337 \mathrm{r}$. na mocy postanowień procesu inowrocławskiego) ${ }^{39}$. To powodowało, że jego działalność kanclerska praktycznie nie miała miejsca. Ponadto z taka sytuacja najprawdopodobniej należy wiązać relatywnie częste używanie przez Bogorię tytułu archidiakona krakowskiego w testacjach różnorakich dokumentów i jednoczesne zarzucenie tytulatury kanclerskiej ${ }^{40}$. Niemniej brak realnej władzy na Kujawach nie przeszkadzał Jarosławowi w zajmowaniu wysokiej pozycji wśród kanclerzy poszczególnych ziem. Według badań przeprowadzonych przez Krzysztofa Ożoga w hierarchii tychże urzędników ustępował on miejsca jedynie kanclerzowi krakowskiemu Zbigniewowi ze Szczyrzyca ${ }^{41}$.

Z początkiem 1335 r. Skotnickiemu oraz Andrzejowi z Veroli została powierzona misja poselska do Awinionu ze skarga przeciwko zakonowi $^{42}$. Stanowiła ona część dyplomatycznych zabiegów króla Kazimierza Wielkiego przeciwko Krzyżakom. Prawdopodobnie to właśnie Bogoria był tym dyplomata, który zawiózł królewska skargę do papieża, a następnie nakreślił mu całą sprawę i przedstawił propozycję króla o odstapieniu połowy nieotrzymanego dotąd od Krzyżaków odszkodowania, czyli 15 tys. grzywien. Niebagatelna rola przypadła też Andrzejowi z Veroli, który jako poseł papieski, kolektor świętopietrza i jednocześnie kanonik krakowski i wrocławski, mógł być wyśmienitym przewodnikiem dla Jarosława po awiniońskiej kurii. Niewykluczone, że na wybór Skotnickiego mogły mieć wpływ także jego kontakty z posłem papieskim Galhardem de Carceribus ${ }^{43}$. Ponadto Bogoria jako kanclerz kujawski, czyli osoba odpowiedzialna za przygotowanie polityki Korony na odcinku polsko-krzyżackim, udał się wraz $\mathrm{z}$ innymi intelektualistami u boku króla na proces w Inowrocławiu w 1337 r. ${ }^{44}$

Naszym zdaniem Jarosław Bogoria zwrócił uwagę na Krzyżaków jeszcze wcześniej. Jak już wyżej zaznaczono, Skotnicki wywodził się

39 J. Kurtyka, Odrodzone Królestwo. Monarchia Wtadystawa Eokietka i Kazimierza Wielkiego $w$ świetle nowszych badań, Kraków 2001, s. 23.

$40 \quad$ K. Ożóg, Intelektualiści..., s. 52.

41 Ibidem, s. 56.

42 Zapewne w związku z tą misją Jarosław nie mógł być obecny u boku króla na zjeździe w Wyszehradzie w 1335 r., zob. J. Tęgowski, Kanclerz kujawski..., s. 45.

43 S. Szczur, Uwagi o działalności..., s. 241-243; K. Ożóg, Intelektualiści..., s. 75. Szerzej na temat wzajemnych kontaktów Jarosława z Galhardem de Carceribus zob. J. Tęgowski, Kanclerz kujawski..., s. 39-49.

$44 \quad$ S. Szczur, Uwagi o działalności..., s. 243; K. Ożóg, Intelektualiści..., s. 75. 
z jednego z najznamienitszych rodów Małopolski. Pozwoliło mu to z jednej strony na odebranie starannego wykształcenia, które otrzymał na najlepszej ówcześnie uczelni prawniczej „Christianitatis” - Bolonii, z drugiej zaś umożliwiło mu także szybką karierę na dworze królewskim. Po powrocie ze studiów w 1322 r. Jarosław bardzo szybko pią się w hierarchii kościelnej ${ }^{45}$, równocześnie musiał dostać się na dwór Władysława Łokietka. Nie wiemy, kiedy dokładnie mogło to nastapić, jednak przebywał tam na tyle długo, aby król zdażył go poznać i docenić jego talent oraz wykształcenie. Powyższe cechy w połaczeniu z przynależnością rodową finalnie poskutkowały powierzeniem mu (wraz ze Spicymirem - mężem Stanisławy, córki Pawła z Bogorii) opieki nad Kazimierzem Wielkim po śmierci króla Władysława oraz wyznaczeniem funkcji doradcy przyszłego monarchy ${ }^{46}$. Jak więc widzimy, sprawami pruskimi Bogoria musiał zainteresować się znacznie wcześniej. Było mało realne, aby jako przedstawiciel rodu mocno związanego z ostatnimi Piastami zasiadajacymi na tronie polskim, a także jako dworzanin królewski, nie orientował się w sytuacji politycznej, w jakiej znalazł się Łokietek. Czyż współczesna elita - a do niej zaliczyć trzeba ród Bogoriów - mogła sobie nie zdawać sprawy z ważkości tej kwestii? Oczywiście, z perspektywy Małopolski sprawa krzyżacka była zapewne inaczej postrzegana niż np. z punktu widzenia Kujaw lub Wielkopolski, ale to nie oznacza, że nie dostrzegano tego zagrożenia. Ponadto, gdy Skotnickiemu powierzano godność kanclerza kujawskiego, było niemożliwe, aby w jakiś sposób nie orientował się w sytuacji panującej na granicy polsko-krzyżackiej, a ściślej rzecz ujmując, na odcinku Kujaw i ziemi chełmińskiej. Nieroztropnością władcy byłoby powierzenie tak ważkiej funkcji osobie, dodajmy w czasie niezażegnanego konfliktu, która nie byłaby zaznajomiona w tej kwestii. To wszystko pozwala nam sądzić, że Bogorię, w większym bądź mniejszym stopniu, zapoznano ze sprawą krzyżacka przed 1331 r. Trudno jednak ściśle ustalić, kiedy mogło to nastapić. Być może miało to miejsce jeszcze przed wyjazdem na studia zagraniczne, wszak w tym czasie jego bracia pełnili wysokie

45 Od 1322 r. kanonik krakowski, 1323-1325 kanclerz kapituły krakowskiej, 1326-1342 archidiakon krakowski, 1325-1342 kanonik sandomierski, kanonik włocławski (1334), posiadał również prebendę kanonika gnieźnieńskiego, zob. M.D. Kowalski, Prałaci i kanonicy krakowskiej kapituty katedralnej od pontyfikatu biskupa Nankera do śmierci Zawiszy z Kurozwęk (1320-1382), Kraków 1996, s. 194. Ponadto J. Tęgowski (Krag rodzinny..., s. 124) przypuszcza, że Jarosław jeszcze przed wyjazdem na studia dzierżył prepozyturę kielecką w 1309 r., dzięki czemu mógł podjąć naukę w Bolonii.

46 Rocznik Traski [w:] MPH, t. 2, s. 858. 
urzędy ziemskie z nadania króla Władysława oraz odgrywali znacząca rolę polityczną w państwie.

Doświadczenie, jakie Jarosław zbierał przez wiele lat, oraz wykształcenie prawnicze zaowocowały 4 lutego $1339 \mathrm{r}$. podczas procesu polsko-krzyżackiego w Warszawie, kiedy to został wyznaczony przez króla na jednego z trzech prokuratorów obok Bertolda z Raciborza oraz Wojciecha, plebana z Bochni i zarazem kapelana królewskiego ${ }^{47}$. Jako prokurator królewski żądał on od zakonu krzyżackiego zwrotu zagarniętych Koronie ziem oraz 200 tys. grzywien odszkodowania ${ }^{48}$. Wedle Tęgowskiego Jarosław również mógł być obecny w czasie pertraktacji pokojowych w Toruniu 31 marca $1339 \mathrm{r}^{49}$, niemniej jest mało prawdopodobne, by nie uwzględniono go jako kanclerza kujawskiego w testacji wystawionego tam dokumentu.

Wybór Bogorii na arcybiskupstwo gnieźnieńskie w 1342 r. oznaczał, że stał się jedną z najważniejszych osób w Koronie. Wszelkie jego działania polityczne miały od tej pory zupełnie inna jakość. Posiadał prawo do kreowania samodzielnej polityki, a przede wszystkim otrzymał do tego odpowiednie instrumenty. Miał jednak świadomość, że urząd ten został mu nadany za pozwoleniem i poparciem monarchy, ponadto nie bez znaczenia była wieloletnia przyjaźń obu dygnitarzy. Kazimierz zawsze mógł liczyć na wsparcie Bogorii, co zauważyła już Kowalska-Urbankowa, śledząc itineraria obu osobistości. Stwierdziła, że przed podjęciem ważnych decyzji król spotykał się $\mathrm{z}$ arcybiskupem, aby zasięgnąc $\mathrm{u}$ niego rady ${ }^{50}$. Wyrazem wzajemnych relacji monarchy i arcybiskupa jest sama tytulatura, jaką znajdujemy na dyplomach królewskich. Na aktach, których wystawca był Kazimierz Wielki, zapis spotykamy odnoszący się do metropolity: „reverendo in Christo patri et principi nostro carissimo domino Iaroslao de Boguria Gneznensis ecclesiae archiepiscopo"51. Takie określenie duchownego nie było spotykane jak dotąd w XIV w., pojawia się ono w źródłach dopiero w XV stuleciu ${ }^{52}$. Nazwanie Jarosława księciem

47 Lites, t. 1, s. 66; H. Chłopocka, Procesy Polski z zakonem krzyżackim w XIV wieku. Studium źródtoznawcze, Poznań 1967, s. 32-33; K. Ożóg, Intelektualiści..., s. 76.

48 Z. Kowalska-Urbankowa, Jarostaw ze Skotnik..., s. 242.

49 J. Tęgowski, Kanclerz kujawski..., s. 48. Za obecnością Bogorii w Toruniu optuje również K. Ożóg, Intelektualiści..., s. 83-84.

50 Z. Kowalska-Urbankowa, Jarostaw ze Skotnik..., s. 71.

51 Np. KDW, t. 3, nr 1401; 1416; 1420; 1433 (tu Jarosław został określony przez monarchę jako „princeps et consiliarus”).

$52 \mathrm{Na}$ przykład tytulaturę książęcą stosowano odnośnie do wielkiego mistrza po zawarciu drugiego pokoju toruńskiego w 1466 r., zob. A. Szweda, „Princeps et con- 
(i doradcą króla) jest tu szczególnie nobilitujacee, zapewne ukazuje też zasługi, jakie wcześniej świadczył metropolita na rzecz monarchy, co spotkało się z uznaniem ze strony króla. Niemniej należy również pamiętać, że w latach 1358-1359 arcybiskup toczył spór z księciem mazowieckim Siemowitem III o niezależność położonego na Mazowszu klucza łowickiego ${ }^{53}$. Jest zatem prawdopodobne, iż król, nazywajacc Skotnickiego księciem, okazywał mu w ten sposób swoje poparcie.

Tuż po objęciu przez Skotnickiego arcybiskupstwa gnieźnieńskiego relacje z zakonem były poniekąd wymuszone - wiązało się to z posiadaniem włości arcybiskupich na terenach należących do władztwa krzyżackiego (chodzi przede wszystkim o terytoria znajdujące się na Pomorzu Gdańskim).

Zanim doszło do uroczystej wymiany dokumentów traktatu pokojowego, zwanego w polskiej historiografii pokojem kaliskim, w lipcu 1343 r. w podinowrocławskich Wierzbiczanach obie strony wielokrotnie ścierały się ze soba, próbując przechylić szalę zwycięstwa za pomoca różnych instytucji: sądu arbitrażowego w Wyszehradzie z 1335 r., rokowań w Inowrocławiu z 1337 r., czy wreszcie procesu kanonicznego, który miał miejsce w Warszawie w 1339 r. Chyba trafne spostrzeżenie w tej materii poczynił Szczur, który zauważył, że „kaliski traktat pokojowy był [...] sumą dyplomatycznych doświadczeń obu układających się stron, a jego postanowienia efektem ówczesnej sytuacji politycznej w Europie Srodkowej" ${ }^{4}$.

Jak wiadomo, początek lat czterdziestych XIV w. to okres, w którym Polska była żywotnie zainteresowana podbojem Rusi Czerwonej, co oczywiście kolidowało z interesami Węgier ${ }^{55}$. Było to poniekąd

siliarus Regni Poloniae”. Król i wielki mistrz w latach 1466-1497 [w:] Od traktatu kaliskiego do pokoju oliwskiego. Polsko-krzyżacko-pruskie stosunki dyplomatyczne w latach 1343-1660, red. A. Bues et seq., Warszawa 2014, s. 241-260; zob. również A. Szweda, Die Rolle der Könige von Polen und ihrer Räte in der Gestaltung der Beziehungen mit den Deutschen Orden von 1333 bis 1453 [w:] Akteure mittelalterlicher Außenpolitik. Das Beispiel Ostmitteleuropas, hrsg. v. S. Flemmig, N. Kersken, Marburg 2017, s. 315-316.

5317 V 1359 r. książę Siemowit III potwierdził posiadanie, wraz z immunitetem sądowym i skarbowym, przez arcybiskupa szczegółowo wyliczonych wsi w kluczu łowickim. Niemniej kwestią sporną były świadczenia i prace, jakie poddani arcybiskupi mieli wykonywać na rzecz księcia (m.in. świadczenia stacyjne), zob. Nowy kodeks dyplomatyczny Mazowsza, t. 3, wyd. I. Sułkowska-Kuraś, S. Kuraś, Warszawa 2000, nr 22, 31; A. Salina, Polityka ksiażat mazowieckich wobec wtadz Kościoła od poczqtku XIV wieku do 1526 roku, Poznań 2001, s. 135, 154.

54 S. Szczur, Traktat pokojowy..., s. 7.

55 Ostatnie badania S. Szczura (Traktat pokojowy..., s. 7-43) oraz D. Wróbla (Kwestia rewindykacji Pomorza w polskiej polityce zagranicznej w latach 1343-1364, 
związane z jednej strony z rozluźnieniem sojuszu polsko-węgierskiego, $z$ drugiej zaś ze zbliżeniem na linii Korona-Luksemburgowie, czego dobitnym przejawem była wizyta Kazimierza Wielkiego w Pradze w lipcu 1341 r., zwieńczona zawarciem sojuszu politycznego. Warto zaznaczyć, że Karol Morawski traktował ów sojusz „koniunkturalnie” 56 . Zmiana sojusznika była związana m.in. z aktualną sytuacją polityczna w kraju. Jej źródła można również upatrywać w zmianie pokoleniowej, jaka miała miejsce wśród osób zasiadających na najważniejszych urzędach państwowych, ze szczególnym uwzględnieniem Małopolski ${ }^{57}$.

Zbliżenie z Luksemburgami, a przede wszystkim uznanie przez Kazimierza Wielkiego podboju Rusi Czerwonej za główny kierunek polityki zagranicznej, nieuchronnie prowadziło do zawarcia pokoju z Krzyżakami. Wiązało się to jednak z konfliktem interesów pomiędzy Polska a Litwa, gdyż oba państwa były żywo zainteresowane ekspansją na Ruś Czerwona - w związku z tym polskiemu monarsze bardzo zależało na ograniczeniu wpływów litewskich na ziemie ruskie. Urzeczywistnić plany króla Kazimierza mógł jedynie zakon krzyżacki, jednak aby taki scenariusz mógł być możliwy, konieczne stało się zawarcie pokoju pomiędzy Koroną a Krzyżakami ${ }^{58}$.

Początkowa faza rozmów nad traktatem kaliskim niestety pozostaje nieoświetlona źródłowo, co daje pole do różnych dywagacji. Niektórzy historycy przyjmuja, że należy ją wiązać z pertraktacjami, które odbyły się w październiku 1341 r. w Toruniu ${ }^{59}$. Prawdopodobnie to na tym zjeździe zwaśnione strony zgodziły się, aby mediatorem został arcybiskup gnieźnieński Janisław, jednak zważywszy na fakt,

„Res Historica” 2005, t. 21, s. 11-28) wykazały, że stosunki polsko-krzyżackie po pokoju kaliskim były podporządkowane ekspansji Kazimierza Wielkiego na Ruś Czerwona.

56 S. Szczur, Traktaty międzypaństwowe Polski piastowskiej, Kraków 1990, s. 62-63.

57 S. Szczur, Traktat pokojowy..., s. 27. Lata 40. i 50. XIV w. to okres, w którym Kazimierz Wielki rozpoczą umiejętną grę polityczna, mająca na celu odsunięcie od rady królewskiej dotychczasowych najwyższych urzędników ziemskich mających wpływ na prowadzoną przez króla politykę. W ich miejsce monarcha powoływał osoby niekojarzone z ówczesnymi elitami, a jednocześnie wobec niego w pełni lojalne. Przejawem takiej polityki królewskiej było celowe nieobsadzanie wakatów na najwyższych urzędach ziemskich Małopolski (kasztelan krakowski, wojewodowie krakowski oraz sandomierski) począwszy od lat 50. aż do połowy lat 60. XIV w., zob. A. Marzec, Rada królewska w monarchii Kazimierza Wielkiego [w:] Narodziny Rzeczpospolitej. Studia $z$ dziejów średniowiecza $i$ czasów wczesnonowożytnych, t. 2, red. W. Bukowski, T. Jurek, Kraków 2012 s. 816-817.

$58 \quad$ S. Szczur, Traktat pokojowy..., s. 28.

59 S. Szczur, Uwagi o działalności..., s. 244. 
iż metropolita w niedługim czasie zmarł, zapewne nie udało mu się podjać żadnych działań mediacyjnych ${ }^{60}$.

Ponieważ Jarosław Bogoria był osobą kluczową przy zawieraniu pokoju kaliskiego pomiędzy Kazimierzem Wielkim a zakonem krzyżackim, warto się pochylić nad porównaniem itinerariów króla Kazimierza oraz arcybiskupa. Umożliwi nam to wyłonienie miejsc, gdzie postaci te się spotykały i gdzie mogły zapaść istotne decyzje związane z pokojem kaliskim ${ }^{61}$. Śledząc podróże obu dostojników, zauważamy, że w pierwszej połowie 1343 r. widzieli się oni kilkukrotnie. Zarówno króla, jak i arcybiskupa odnajdujemy 2 marca w Poznaniu, gdzie Kazimierz Wielki dokonał przeniesienia z prawa polskiego na prawo średzkie wsi Stodoły należącej do klasztoru w Trzemesznie ${ }^{62}$, po czym ich drogi się rozchodza: monarcha wraca do Krakowa ${ }^{63}$, Bogoria zaś podróżuje do swych posiadłości w kluczu żnińskim ${ }^{64}$. Ich następne spotkanie rejestrujemy 13 czerwca, czyli niespełna miesiąc przed zawarciem pokoju kaliskiego. Ma ono miejsce również w Poznaniu, gdzie król wystawił dokument sprzedaży wsi Wawrzyszkowo (późniejszy Kamień) położonej nad rzeką Kamion ${ }^{65}$. Obaj, zapewne 15 czerwca $^{66}$, opuścili Poznań i pojechali do Gniezna, gdzie dowodnie byli już dwa dni później67. Prawdopodobnie Kazimierz Wielki przebywał tam aż do chwili, gdy jego orszak na początku lipca wyruszył do Kalisza. Z wielka dozą prawdopodobieństwa możemy stwierdzić, że jeżeli miało dojść do konsultacji Kazimierza Wielkiego z Jarosławem Bogorią w sprawie pokoju kaliskiego, to nastapiło to do końca czerwca 1343 r. W Poznaniu lub Gnieźnie musiały więc zapaść kluczowe decyzje odnoszące się do zawarcia wieczystego pokoju z Krzyżakami. Źródła informuja, że monarcha był obecny w Kaliszu już 4 lipca ${ }^{68}$, jednak nie zachowało się żadne potwierdzenie źródłowe co do obecności w tym dniu Jarosława. Mimo wszystko jest bardzo

60 Ibidem, s. 244.

61 Podstawą do porównania itinerarium Jarosława Bogorii jest itinerarium Kazimierza Wielkiego opracowane przez Antoniego Gassiorowskiego (Itinerarium króla Kazimierza Wielkiego. Materiaty 1333-1370, „Roczniki Historyczne” 1998, t. 64, s. 175-208).

62 KDW, t. 2, nr 1211.

63 KDP, t. 3, nr 93.

64 KDW, t. 2, nr 1213.

65 Ibidem, nr 1214.

66 Z datą 15 VI 1343 r. widnieje ostatni dokument potwierdzający obecność Kazimierza Wielkiego w Poznaniu, zob. ibidem, t. VI, nr 131.

67 Ibidem, t. II, nr 1216.

68 Długosz, lib. IX, s. 227. 
prawdopodobne, iż Bogoria przybył do Kalisza razem z królem - wszak bez niego mediacje nie mogły się odbyć. Wystapienie arcybiskupa w Kaliszu zostało odnotowane jedynie 8 lipca ${ }^{69}$.

Nieco ponad rok po elekcji Jarosława na tron arcybiskupi w Gnieźnie musiał on sprostać nie lada wyzwaniu: została mu powierzona rola mediatora pomiędzy zwaśnionymi stronami. W rozwiązywaniu konfliktów pomiędzy władcami częstokroć odwoływano się do instytucji sądu polubownego lub pośrednictwa innego panującego, należy jednak pamiętać, że granica pomiędzy obiema instytucjami była płynna: zdarzało się, że mediator był jawnym stronnikiem bądź wręcz poddanym którejś ze stron ${ }^{70}$. Przykładem takiego działania (co prawda piętnastowiecznego) jest chociażby wyznaczenie wielkiego księcia litewskiego Witolda do rozstrzygnięcia sporu polsko-krzyżackiego w 1408 r. Władca Litwy był wtedy formalnie podległy królowi Władysławowi Jagielle, a mimo to odwołano się do jego usług $^{71}$. Wracajac jednak do kwestii Kalisza. Zwaśnione strony nie rozmawiały ze sobą bezpośrednio, lecz wyłącznie za pośrednictwem mediatora. Znaczenie Jarosława Bogorii w negocjacjach prowadzących do zawarcia pokoju zostało odnotowane wprost w dwóch dyplomach należących do zespołu dokumentów traktatowych. W pierwszym z nich Kazimierz Wielki obiecał nie wspierać pogan przeciwko zakonowi krzyżackiemu. Uczynił to dla dobra wszystkich wierzacych w Jezusa Chrystusa oraz „ob reverenciam venerabilis in Christo patris domini Iaroslai divina providencia sancte Gneznensis ecclesie archiepiscopi, et propter conplementum ordinacionis per ipsum dominum archiepiscopum facte inter nos, ex una, et religiosos viros dominum magistrum"72. Drugi dokument, w którym wybrzmiała rola arcybiskupa Jarosława, to instrument notarialny opisujacy ratyfikację pokoju kaliskiego na polu między wsiami Murzynno oraz Wierzbiczany zawartego pomiędzy królem Kazimierzem Wielkim a wielkim mistrzem zakonu krzyżackiego Ludwigiem Königiem ${ }^{73}$. Warto zauważyć, iż Bogoria, poza tym że pełnił funkcję mediatora, sam również był

69 KDW, t. 2, nr 1217; t. 6, nr 132a.

70 A. Szweda, Sad arbitrażowy $w$ bilateralnych stosunkach polsko-krzyżackich w pierwszej połowie XV wieku [w:] Narodziny Rzeczypospolitej..., s. 946; szerzej na temat instytucji arbitrażu zob. R. Wojciechowski, Arbitra $\dot{z} w$ doktrynie prawnej średniowiecza, Wrocław 2010.

$71 \quad$ A. Szweda, Sad arbitrażowy..., s. 947.

72 PrUb, Bd. 3, nr 568 (=KDW, t. 2, nr 1217).

73 PrUb, Bd. 3, nr 589. 
stroną w konflikcie, ponieważ Krzyżacy w czasie konfliktów polsko-krzyżackich wielokrotnie pustoszyli dobra archidiecezji gnieźnieńskiej, a ponadto Skotnicki był poddanym króla polskiego. Niestety, szczupłość materiału źródłowego, jakim dysponujemy dla XIV w., sprawia, że nie posiadamy zbyt wielu informacji traktujących o działaniach, które na tej niwie podejmował Jarosław Bogoria. Zważywszy na fakt, że na sprawę krzyżacką w samej Koronie spoglądano niejednoznacznie, być może Skotnicki jako Małopolanin zasiadajacy na stolicy arcybiskupiej w wielkopolskim Gnieźnie starał się znaleźć złoty środek, aby pogodzić sprzeczne interesy poszczególnych ziem wchodzacych w skład Królestwa Polskiego ${ }^{74}$. Jest znamienne, że w traktacie kaliskim eksponowano zarówno znaczenie, jak i zasługi arcybiskupa Jarosława, który miał przyczynić się do zawarcia wieczystego pokoju pomiędzy adwersarzami ${ }^{75}$. Ponadto jako jedna ze stron w konflikcie arcybiskup był dwukrotnie współwystawca dyplomów spisanych według identycznego formularza. Pierwszy akt został wystawiony przez niego oraz biskupów włocławskiego i poznańskiego ${ }^{76}$, w drugim dokumencie natomiast do tego samego grona dołączył jeszcze biskup płocki ${ }^{77}$. Dyplomy te dotyczyły zrzeczenia się roszczeń powstałych na skutek wojny z zakonem na terytoriach kościelnych (ich wystawienia żądali przedstawiciele zakonu krzyżackiego, co zapewne było związane z zasadą wzajemności) ${ }^{78}$. Przedstawiciele episkopatu, których dobra ucierpiały w starciach zbrojnych, odstapili od możliwości żądania w przyszłości ewentualnego wynagrodzenia strat ${ }^{79}$. Wymiana dokumentów traktatowych (ich treść ustalono w Kaliszu) nastapiła 23 lipca 1343 r. na polu pomiędzy Wierzbiczanami (wsia leżąca w granicach Królestwa Polskiego) a Murzynnem (wsią należącą do władztwa zakonnego). Z instrumentu notarialnego wówczas wystawionego wiadomo, że ratyfikacja składała się z czterech etapów. Pierwszym z nich było przybycie Jarosława Bogorii do namiotu wielkiego mistrza z dokumentami traktatowymi strony polskiej, po czym Krzyżacy przystapili do oględzin dyplomów zarówno pod względem

74 S. Szczur, Traktat pokojowy..., s. 28.

75 PrUb, Bd. 3, nr 568, 589.

76 Ibidem, nr 574.

77 Ibidem, nr 575 (= KDW, t. 2, nr 1223).

78 Gwarantami pokoju kaliskiego ze strony polskiej nie byli wyłącznie przedstawiciele episkopatu. O świeckich testatorach zob. np. A. Gąsiorowski, Polscy gwaranci traktatów z Krzyżakami XIV-XV wieku, KMW 1971, nr 2-3, s. 245-265.

79 S. Szczur, Traktat pokojowy..., s. 29, 31. 
treści, jak i przywieszonych doń pieczęci. Następnie w analogiczny sposób Skotnicki postapił z dokumentami zakonnymi, przedstawiając je Kazimierzowi Wielkiemu. Druga faza nastapiła po krótkiej przerwie. Król i Ludwig König spotkali się pod gołym niebem na polu i przywitali. Trzecia część to obwieszczenie przez Jarosława w obecności obu zwaśnionych stron (,,assistentibus rege, magistro et omni multitudine”) postanowień pokoju oraz uroczysta wymiana dokumentów rozejmowych. Ostatni etap polegał na zaprzysiężeniu przez monarchę (,per coronam capitis sui”) i wielkiego mistrza (,tactu crucis sue”) postanowień pokoju kaliskiego oraz uroczystym pocałunku pokoju pomiędzy królem i wielkim mistrzem ${ }^{80}$. Następnie Jarosław Bogoria w asyście obecnych członków episkopatu Polski ogłosił, że zrzeczenie się praw do Pomorza oraz ziem chełmińskiej i michałowskiej przez Kazimierza Wielkiego było wielką donacją na rzecz Krzyżaków ${ }^{81}$.

Postanowienia pokoju kaliskiego nie pozostały bez wpływu na późniejsze relacje pomiędzy metropolita a zakonem. Chodzi przede wszystkim o regulacje spraw gospodarczych dóbr znajdujących się na Pomorzu. Już na przełomie października i listopada 1344 r. Bogoria wraz ze swoją kapitułą układał się z Krzyżakami w sprawie dóbr arcybiskupstwa gnieźnieńskiego usytuowanych na terenie władztwa krzyżackiego. Ugoda dotyczyła zmiany sposobu pobierania dziesięciny, płatnej na świętego Marcina (11 listopada), która od tej pory miała wynosić dwa skojce od każdego uprawianego łanu, zamiast dziesięciny wytycznej. Dokonano wówczas również zamiany dóbr: arcybiskup przekazał wielkiemu mistrzowi wieś Chojniczki, w zamian zaś otrzymał sto łanów w Gębarzewie zwanym też Bischofswalde, znajdującym się w okolicach Człuchowa; ponadto wielki mistrz potwierdził wcześniejsze przywileje księcia Mściwoja II dla Kościoła gnieźnieńskiego z lat 1284 i 1290 oraz nadał pewne wolności dla wsi Lubiewo i Sucha ${ }^{82}$. Warto zaznaczyć, że w stosunku do metropolity zauważono,

80 PrUb, Bd. 3, nr 589; Ch.F. Weber, Urkunden in der symbolischen Kommunikation zwischen dem Deutschen Orden und Polen. Friedensschluss und Konfliktführung im 14. Jahrhundert [w:] Mittelalterliche Kultur und Literatur im Deutschordensstaat in Preußen. Leben und Nachleben, hrsg. v. J. Wenta, S. Hartmann, G. Vollmann-Profe, Toruń 2008, s. 313-320 (zwłaszcza s. 315-316); A. Szweda, Die Rolle..., s. 313-314.

81 PrUb, Bd. 3, nr 590; S. Szczur, Traktat pokojowy..., s. 32.

82 PrUb, Bd. 3, nr 675 (= KDW, t. 2, nr 1234), 684 (= KDW, t. 2, nr 1235), 686 (= KDW, t. 2, nr 1236); A. Gąsiorowski, I. Skierska, Poczatki oficjalatu kamieńskiego archidiecezji gnieźnieńskiej (wiek XIV-XV), KH 1996, t. 103, s. 11-12; M. Grzegorz, Pomorze Gdańskie pod rzadami zakonu krzyżackiego w latach 1308-1466, Bydgoszcz 2007, s. 126. 
jakoby miał on uczynić wiele przyjacielskich gestów zarówno wobec wielkiego mistrza Ludwik Königa, jak i jego zakonu ${ }^{83}$. Biorąc pod uwage znaczenie Skotnickiego w zawarciu pokoju kaliskiego, słowa skierowane pod jego adresem możemy rozpatrywać nie w kontekście jakiegoś kurtuazyjnego zwrotu formularzowego, lecz wręcz przeciwnie - jako odzwierciedlenie relacji, jaka wówczas istniała pomiędzy nim a zakonem.

Jak już odnotowano w literaturze przedmiotu, od 1345 r. Jarosław przystapił do reformowania swoich włości na Pomorzu ${ }^{84}$. W tymże roku przywilej lokacyjny na prawie chełmińskim otrzymała Wielka Cerekwica $^{85}$, w 1347 r. natomiast takie prawa posiadały już Cerekwica Nowa (Obkas) i Orzełek (Orle) ${ }^{86}$. Z dnia 28 września 1348 r. pochodzi dyplom wystawiony przez komtura tucholskiego Konrada Vullekopa, który zaświadczył, że niejaki Wawrzyniec z Pamiętowa za zgodą swojej matki oraz żony sprzedał swoje dobra zwane „Grisov”, położone w pobliżu wsi Lubnia, sołtysowi oraz chłopom z tejże wsi, będącymi poddanymi Jarosława ${ }^{87}$. Jak dotąd nie rozstrzygnięto jednoznacznie identyfikacji tych miejscowości. Jeżeli przychylić się do dywagacji Maksymiliana Grzegorza, można by identyfikować Lubnie z Lubiewem należącym do posiadłości pomorskich arcybiskupstwa gnieźnieńskiego $^{88}$. Z kolei 7 czerwca 1349 r. Jarosław nadał niejakim braciom Bernardowi i Janowi jako sołtysom wspomniana już wyżej wieś Gębarzewo (Bischofswalde) na prawie chełmińskim ${ }^{89}$. Odnośny dokument wystawił w Wielkiej Cerekwicy, co dowodzi, że arcybiskup swobodnie przebywał w swoich posiadłościach znajdujących się na terenie władztwa krzyżackiego.

Kolejnym potwierdzeniem zaufania, jakim Kazimierz Wielki darzył Jarosława Bogorię, był układ graniczny w Trzęsaczu zawarty w 1349 r. Co prawda nie sa jasne okoliczności jego wynegocjowania, niemniej w literaturze przedmiotu przypuszcza się, jakoby Skotnicki wraz z biskupem poznańskim Wojciechem Pałuką byli głównymi negocjatorami ze strony polskiej, po stronie krzyżackiej natomiast mieli

$83 \quad$ PrUb, Bd. 3, nr 687.

84 A. Gasiorowski, I. Skierska, Poczatki..., s. 12.

85 Wizytacje dóbr arcybiskupstwa gnieźnieńskiego i kapituły gnieźnieńskiej z XVI wieku, wyd. B. Ulanowski, Kraków 1920, s. 319.

86 PrUb, Bd. 4, nr 274, 275; A. Gąsiorowski, I. Skierska, Poczatki..., s. 12.

87 PrUb, Bd. 4, nr 353.

88 M. Grzegorz, Pomorze Gdańskie..., s. 128.

89 PrUb, Bd. 4, nr 420. 
nimi być wielki komtur Winrych von Kniprode oraz wielki szpitalnik Herman von Kudorf. Domniemanie to oparte jest na umieszczeniu tych osób w formułach korroboracyjnych interesujących nas dokumentów. Negocjacje rozpoczęły się zapewne nie wcześniej niż 8 czerwca, gdyż 7 czerwca Bogoria przebywał jeszcze w Cerekwicy ${ }^{90}$. Za tym, że Jarosław pełnił funkcję głównego negocjatora może przemawiać m.in. to, że arcybiskup był zaznajomiony z topografia terenu - posiadał on wszak swoje włości w granicach zakonnych, a co za tym idzie, znał również problemy związane z tym faktem. Jak już wspomniano, Skotnicki 7 czerwca przebywał w Cerekwicy, gdzie wydał dokument lokacyjny dla swoich dóbr w komturstwie człuchowskim, był zatem na bieżąco ze sprawami krzyżackimi. Także po polskiej stronie granicy metropolita miał posiadłości w okolicach Żnina, co zapewne sprawiało, że żywotnie się interesował załagodzeniem sporu granicznego - pokój na granicy był mu jak najbardziej na rękę, ponieważ zabezpieczał jego dobra przed grabieżą.

Adam Szweda stwierdził ponadto, że pomiędzy czerwcem 1349 r. a sierpniem 1350 r. za pośrednictwem Jarosława Bogorii został zawarty układ pomiędzy królem Kazimierzem Wielkim a wielkim mistrzem Henrykiem Dusemerem. Miał on załagodzić konflikt, jaki pojawił się między kupcami polskimi a toruńskimi. Badacz ten swoją tezę opiera na dokumencie wystawionym 24 sierpnia $1350 \mathrm{r}$. we Lwowie przez Kazimierza Wielkiego, w którym władca zobowiązał się do przestrzegania ugody zawartej między nim a wielkim mistrzem za pośrednictwem arcybiskupa Jarosława, a ponadto zapewnił, że nie będzie w stosunku do mieszczan toruńskich wysuwał żadnych pretensji ${ }^{91}$. Niemniej należy się zastanowić, czy aby na pewno podpisano jakieś porozumienie. Wedle treści dokumentu ugoda została zawarta „inter nos [tzn. Kazimierzem Wielkim] et venerabilem ac religiosum virum dominum Henricum Thusmer magistrum generalem ordinis sancte Marie domus Theotonice medianto reverendo in Christo patre nostro domino Jaroslao divina providencia sancte Gneznensis ecclesia archiepiscopo alias amicabiliter ordinatam"92. Zdecydowanie wypada nam odrzucić utożsamianie owej ugody z pokojem kaliskim z 1343 r. Pomimo że - począwszy od pertraktacji pokojowych w Kaliszu - przy wielu okazjach podkreślano rolę i zasługi

\footnotetext{
A. Szweda, Królestwo Polskie..., s. 15-16.

91 PrUb, Bd. 4, nr 610. A. Szweda, Królestwo Polskie..., s. 18-22.

92 Ibidem, nr 610.
} 
Jarosława Bogorii w zawarciu wieczystego pokoju pomiędzy Królestwem a zakonem krzyżackim ${ }^{93}$, pamiętajmy jednak, że pokój kaliski został zawarty przez ówczesnego wielkiego mistrza Ludwiga Königa, interesujące nas źródło zaś wyraźnie wskazuje na zawarcie porozumienia pomiędzy Kazimierzem Wielkim a Henrykiem Dusemerem. W grę wchodzi zatem układ delimitacyjny w Trzęsaczu z 1349 r. bądź jakieś inne wydarzenie polityczne, które pozostaje niepotwierdzone źródłowo. W pierwszym przypadku nie dysponujemy konkretna informacją o prowadzeniu rozmów przez Jarosława, jednak koncepcja oparta na formule korroboracyjnej w pełni zasługuje na akceptację. W związku z powyższym wymienienie Jarosława Bogorii jako osoby, dzięki której została zawarta ugoda, należy odnieść do Trzęsacza bądź domniemanej ugody handlowej zawartej przed sierpniem $1350 \mathrm{r}$. Jeżeli rzeczywiście miała ona miejsce, to odpowiednie dokumenty się nie dochowały, niemniej w związku ze szczupłością materiału źródłowego dla tego okresu kwestii tej nie sposób jednoznacznie rozstrzygnąć

Pomimo lokacji na prawie chełmińskim w 1349 r. wsi Gębarzewo (Bischofswalde) Jarosław w 1356 r. zdecydował się na wymianę jej oraz Brudzewa k. Pucka (diecezja włocławska) na wieś Dąbrówka (Bogoria zatwierdził układ z zakonem 22 kwietnia 1357 r. w Gnieźnie). Arcybiskup z zamienianych wsi otrzymywał inną dziesięcinę niż dotychczas mu przysługiwała - dwa skojce z każdego łanu. Warto zauważyć, że Gębarzewo Skotnicki wcześniej otrzymał również droga zamiany za wieś Chojniczki ${ }^{94}$. Wspomniane wyżej dobra arcybiskupie, czyli Wielka Cerekwica, Obkas, Dąbrówka, Lubiewo, Sucha, a także leżące w pobliżu Świecia Gruczno i Kozielec, znalazły się w kluczu dóbr kamieńskich z siedzibą w Kamieniu zarządzanych w imieniu arcybiskupa przez prokuratorów ${ }^{95}$. Wymiana tych dóbr wpisywała się w akcję komasacji włości arcybiskupich, prowadzonej przez Bogorię na terenach należących do Korony, oraz podnoszenia ich statusu ekonomicznego ${ }^{96}$. Być może należy dopatrywać się również jakiegoś związku pomiędzy wymianami dóbr arcybiskupich na Pomorzu Gdańskim z zakonem krzyżackim a akcją osadniczą prowadzoną

93 Zob. np. : KDW, t. 2, nr 1217; PrUb, Bd. 3, nr 589; 687.

94 PrUb, Bd. 5, nr 477, 489, 523.

95 A. Gasiorowski, I. Skierska, Poczatki..., s. 12-13. O jedynym potwierdzonym źródłowo prokuratorze kamieńskim Klemensie z Mechnacza zob. Ł. Włodarski, Dwór i najbliższe otoczenie..., s. 243, 253.

96 K. Stachowska, Jarostaw Bogoria..., s. 2. 
w latach czterdziestych XIV w. w południowej części komturstwa człuchowskiego ${ }^{97}$.

Prawdopodobne jest również to, że Jarosław Bogoria jako najbliższy współpracownik Kazimierza Wielkiego brał udział w podróży królewskiej do Malborka w październiku 1365 r., czego w każdym razie nie wyklucza itinerarium arcybiskupie ${ }^{98}$.

Ostatnie lata pontyfikatu Jarosława Bogorii ze Skotnik sa stosunkowo dobrze znane dzięki Kronice Jana z Czarnkowa. Wiadomo, że w grudniu $1371 \mathrm{r}$. arcybiskup stracił wzrok. Ślepota w połączeniu z podeszłym wiekiem miały być przyczyną ustapienia Skotnickiego ze stolicy arcybiskupiej. Wówczas bratanek Bogorii, a zarazem prepozyt gnieźnieński, Mikołaj z Kożuchowa, podsunął mu pomysł, aby to jemu wuj odstapił arcybiskupstwo. Spotkało się to z aprobatą Skotnickiego. Dał Mikołajowi cesję wraz z potrzebnymi listami, z którymi prepozyt gnieźnieński udał się bez zgody kapituły katedralnej oraz króla Ludwika do kurii rzymskiej w celu zatwierdzenia go na tym beneficjum przez papieża. Wedle kronikarza taki obrót spraw nie spodobał się kantorowi gnieźnieńskiemu Januszowi z Wolicy. Miał on zebrać niektórych prałatów oraz kanoników gnieźnieńskich i po naradzie wydał, a następnie sam zawiózł do Rzymu listy, które miały uniemożliwić promocję Mikołaja na arcybiskupstwo gnieźnieńskie. Akcja przyniosła spodziewany efekt ${ }^{99}$. Ostatecznie Jarosław w 1373 r. złożył rezygnację i przekazał ją na ręce Janusza Suchegowilka, który był synem córki Pawła Bogorii. Z Kroniki Jana z Czarnkowa wiemy, że ostatecznie to jego wybrał, za aprobatą Ludwika Węgierskiego, na swojego następcę. Jarosław wysłał wtedy delegację do papieża Grzegorza XI, na której czele stali kanonik gnieźnieński Jarand z Bełszewa oraz rycerz Domarad z Pierzchna. Jednak nie udało im się uzyskać papieskiej konfirmacji, a to dlatego, że król rozmyślił się i wysłał do Rzymu stosowne pisma. Po powrocie delegacji do kraju Janusz Suchywilk zaopatrzył się w listy króla węgierskiego i polskiego Ludwika, cesarza rzymskiego i króla czeskiego Karola oraz kapituły

97 K. Kasiske, Das deutsche Siedelwerk des Mittelalters in Pommerellen, Königsberg 1938, s. 165-166.

98 Z zachowanego materiału źródłowego wiadomo, że Jarosław 2 IX 1365 r. przebywał w Opatówku (KDW, t. 6, nr 213), następnie jego pobyt rejestrujemy 15 XI w Żninie (ibidem, t. 3, nr 1552). Szerzej na temat królewskiej wizyty w Malborku zob. A. Szweda, Okoliczności wizyty króla Kazimierza Wielkiego w Malborku w 1365 roku, „Roczniki Historyczne" 2011, t. 77, s. 83-100.

99 Kronika, s. 652-653. 
gnieźnieńskiej, po czym osobiście się udał do Rzymu. Dotarł tam około 6 stycznia $1374 \mathrm{r}$. Papież przyjął go, a następnie zatwierdził na stolicy arcybiskupiej, polecił także wyświęcić go na arcybiskupa w druga niedzielę po Wielkanocy. Zaraz po tym rzeczony pospiesznie udał się w drogę powrotną do Gniezna. Przybył tam w pierwszą sobotę lipca, a już następnego dnia celebrował mszę, na której był obecny biskup poznański oraz szlachta ${ }^{100}$.

Wart uwagi jest także fakt zatrzymania przez Jarosława na swoje utrzymanie - po jego rezygnacji ze stolicy arcybiskupiej - m.in. wszystkich dochodów z Pomorza Gdańskiego (,Dominus autem Jaroslaus olim archiepiscopus omnes reditus in Pomorania et castrum Opathow cum villis adjacentibus et decimas in districtu Kalisiensi reservabat pro sui sustentatione, quam reservationem sedes apostolica confirmavit") ${ }^{101}$. Słowa Jana z Czarnkowa znajdują również potwierdzenie w bulli papieża Grzegorza XI z 16 maja 1374 r., w której dochody z dóbr stołowych na Pomorzu Gdańskim wraz z dochodami z klucza opatowskiego stanowią część uposażenia Jarosława Bogorii $^{102}$. Zatrzymanie przez Skotnickiego włości arcybiskupich na Pomorzu należałoby chyba rozpatrzyć przez pryzmat uregulowania ich sytuacji ekonomicznej oraz stabilnej sytuacji tychże dóbr arcybiskupich na obszarze podległym zakonowi krzyżackiemu, a nie dobrych osobistych relacji arcybiskupa z Krzyżakami. Aczkolwiek nie można wykluczać, że gdyby arcybiskup nie zdawał sobie sprawy ze stabilności tych posiadłości oraz gdyby dochody z tych włości były zagrożone przez działalność Krzyżaków, to nie chciałby ich pozostawiać na swoje utrzymanie.

Jak wcześniej wspomniano, następcą Skotnickiego na arcybiskupstwie gnieźnieńskim był Janusz Suchywilk, mamy więc do czynienia z sytuacja, w której arcybiskupa seniora oraz nowego metropolitę łączą więzy rodzinne. Ponadto uzyskał on ów urząd niejako za pozwoleniem Bogorii, w związku z czym trudno dopatrywać się obdarowania Jarosława dochodami z podrzędnych wsi należących do mensy arcybiskupiej w celu zaspokojenia jego doczesnych potrzeb (tym bardziej że Opatów należał do dobrze usytuowanych kluczy majątkowych mensy arcybiskupiej). Wszak wiemy, że przez cały pontyfikat dokładał on wszelkich starań, aby podnieść status materialny swoich dóbr,

\footnotetext{
100 Ibidem, s. 653-654.

101 Ibidem, s. 654.

102 KDW, t. 3, nr 1703; A. Gasiorowski, I. Skierska, Poczatki..., s. 13.
} 
niemniej jest oczywiste, że jako senior nie otrzymał najbogatszych kluczy ziemskich, np. łowickiego czy żnińskiego.

Konstatacje, jakie wynikaja z powyższych rozważań, można zebrać w następujacych punktach:

1. Jarosław Bogoria zwrócił uwagę na sprawy krzyżackie przed 1331 r., czyli przed objęciem przez niego kanclerstwa kujawskiego. Jako przedstawiciel możnowładczej rodziny, z której wywodziło się wielu znaczących urzędników ziemskich w Małopolsce, ponadto jako osoba starannie wykształcona jest niemożliwe, aby nie był zaznajomiony z aktualnymi i ważkimi kwestiami politycznymi Korony.

2. Jako doradca królewski musiał wpływać na kształtowanie polityki zagranicznej króla, ponadto uzyskanie stanowiska kanclerza sprawiło, że był odpowiedzialny za koncepcję polityki polsko-krzyżackiej. Zapewne to z jego strony wyszło wiele inicjatyw związanych z rozwiązaniem sprawy krzyżackiej.

3. Doświadczenie, jakie zebrał podczas kontaktów z Krzyżakami, zaowocowało podczas procesu warszawskiego w 1339 r., kiedy został wyznaczony na jednego z trzech prokuratorów polskich, a następnie, już jako arcybiskup, podczas zawierania pokoju w Kaliszu w 1343 r. oraz układu granicznego w Trzęsaczu w 1349 r.

4. Od momentu wyboru na arcybiskupstwo gnieźnieńskie Jarosław stał się samodzielnym politykiem, a nie wykonawca woli monarchy, jednak związki, w jakich pozostawał z królem Kazimierzem Wielkim, sprawiały, że obie te osobistości ze sobą współpracowały. Ponadto Jarosław był najważniejszym i najbliższym doradca polskiego władcy.

5. Relacje Jarosława jako arcybiskupa gnieźnieńskiego z zakonem krzyżackim były poniekąd wymuszone. Wiązało się to z kwestią posiadania przez Kościół gnieźnieński dóbr stołowych na terytoriach zarządzanych przez Krzyżaków (Pomorze Gdańskie). Ponadto nie bez znaczenia jest przynależność części ziem Pomorza do diecezji gnieźnieńskiej i włocławskiej, która wchodziła w skład metropolii gnieźnieńskiej.

6. Zawarcie pokoju kaliskiego umożliwiło arcybiskupowi gnieźnieńskiemu przeprowadzenie akcji modernizacji dóbr położonych w granicach zakonnych oraz swobodne w nich przebywanie. 
7. Po objęciu przez Bogorię arcybiskupiego Gniezna jego kontakty z zakonem krzyżackim były przynajmniej poprawne. Jako doradca króla i zarazem zwolennik jego polityki musiał się w nią wpisywać. Jarosław akceptował i realizował nadrzędność sprawy Rusi Czerwonej w polityce Korony, czego przejawem były stosunki z Krzyżakami.

8. Arcybiskup cieszył się poważaniem ze strony krzyżackiej. Wyrazem tego było powierzanie mu prowadzenia negocjacji w Kaliszu, a także akceptacja jego osoby jako prowadzacego rozmowy w sprawie układu delimitacyjnego w Trzęsaczu w $1349 \mathrm{r}$.

9. Metropolita współdziałał z zakonem w sprawie jego dóbr znajdujących się w granicach władztwa zakonnego. Dokonywał zamian dóbr i nie stawiał przeszkód Krzyżakom w prowadzeniu przez nich akcji osadniczej w komturstwie człuchowskim w latach czterdziestych XIV w., sam ponadto korzystał z zamian włości w związku z realizacją polityki komasacji dóbr oraz podnoszenia ich statusu ekonomicznego poprzez sprzedaż sołectw na prawie niemieckim.

10. Zatrzymanie sobie dochodów z Pomorza Gdańskiego po rezygnacji z tronu gnieźnieńskiego należy prawdopodobnie uważać za przejaw dobrych relacji na linii arcybiskup senior-zakon krzyżacki. Gdyby Jarosławowi groziło jakieś niebezpieczeństwo ze strony krzyżackiej bądź jego relacje z nimi nie układały się pomyślnie, najprawdopodobniej zachowałby na swoje utrzymanie inne włości.

\author{
Abstract \\ Relations of the archbishop of Gniezno Jarosław Borogia \\ of Skotniki with the Teutonic Order in Prussia
}

The paper concerns the relations between the archbishop of Gniezno Jarosław Borogia of Skotniki with the Teutonic Order in Prussia in the years 1342-1374. The first challenge the new metropolitan bishop had to face was the conclusion of a peace treaty between king Casimir III the Great and the Grand Master of the Teutonic Order Ludwig König in Kalisz in 1343. His success allowed him to strengthen his position in the relationship with the Teutonic Order and, in consequence, led to the reorganisation of the "table estate" (bona mensae regiae) located on 
the territory of the Teutonic Order. In June 1349 Jarosław was, on the Polish side, one of the two negotiators of the delineation treaty concluded in Trzessacz. He most likely went to Marienburg in the autumn of 1365 with the king. An interesting aspect, which should be viewed through the prism of the good relations with the Order, is that after Jarosław resigned from the position of archbishop, the property that was to be his sustenance remained in the territory of the State of the Teutonic Order. 